\title{
PENERAPAN METODE K-MODES UNTUK PROSES PENENTUAN PENERIMA BANTUAN LANGSUNG TUNAI (BLT)
}

\author{
Yolanda Aprilia Putri Kartikasari, Yosep Agus Pranoto, Deddy Rudhistiar \\ Program Studi Teknik Informatika S1, Fakultas Teknologi Industri \\ Institut Teknologi Nasional Malang, Jalan Raya Karanglo km 2 Malang, Indonesia \\ 1718024@scholar.itn.ac.id
}

\begin{abstract}
ABSTRAK
Pendataan calon penerima BLT Desa Jatikerto sudah dilakukan dengan menggunakan teknologi yaitu Microsoft Excel. Terdapat beberapa kriteria yang harus dipertimbangkan agar penyaluran dana BLT tepat sasaran. Dalam proses penentuan penerima BLT biasanya sering terjadi kendala. Kendala tersebut dikarenakan banyaknya data calon penerima BLT dan kesulitan dalam memproses data karena membutuhkan waktu yang lama serta memiliki kemungkinan yang lebih besar menghasilkan kesalahan saat menentukan penerima BLT.

Sistem yang dibuat menerapkan metode K-Modes Clustering untuk proses penentuan penerima BLT. Sehingga dapat membantu memudahkan petugas dalam menentukan penerima BLT dan dapat mempersingkat waktu dalam pengolahan data. Sistem ini dirancang berbasis website dengan phpMyAdmin sebagai databasenya untuk memudahkan admin atau pihak desa dalam mengakses sistem dimana saja.

Berdasarkan hasil pengujian sistem yang telah dilakukan, sistem penentuan penerima BLT cukup baik dalam mengklusterkan data penerima BLT terhadap algoritma k-modes clustering digunakan data lama BLT desa Jatikerto dan didapatkan nilai $96,875 \%$. Dari hasil pengujian sistem error didapatkan nilai error $0 \%$. Dari hasil pengujian user admin didapatkan nilai $25 \%$ sangat setuju dan $75 \%$ setuju, sedangkan dari hasil pengujian user warga didapatkan nilai 8,3\% sangat setuju, $87,5 \%$ setuju dan 4,2\% kurang setuju.
\end{abstract}

Kata Kunci : Desa jatikerto, Bantuan Langsung Tunai (BLT), K-Modes Clustering, Website.

\section{PENDAHULUAN}

Di Indonesia masalah kemiskinan merupakan salah satu permasalahan yang sulit diselesaikan oleh pemerintah. Kemiskinan yang terjadi pada masyarkat Indonesia merupakan masalah utama yang menjadi perhatian di berbagai pemerintahan provinsi, kabupaten, kota, kecamatan dan desa. Berbagai cara penanggulangan kemiskinan telah dilakukan oleh pemerintah salah satunya adalah pemberian bantuan langsung tunai (BLT). Diharapkan melalui program pemberian BLT dapat mengatasi permasalahan yang dialami setiap warga kurang mampu khususnya permasalahan ekonomi.

Proses pendataan penerima bantuan Desa Jatikerto sudah dilakukan dengan menggunakan teknologi yaitu Microsoft Excel. Terdapat beberapa kriteria dan pertimbangan lain yang harus diperhatikan agar penyaluran dana bantuan desa tepat sasaran. Namun dalam proses penentuan penerima bantuan, biasanya sering terjadi kendala. Kendala tersebut dikarenakan banyaknya data penerima bantuan dan kesulitan dalam memproses data karena membutuhkan waktu yang lama serta memiliki kemungkinan yang lebih besar menghasilkan kesalahan saat menentukan penerima bantuan desa.

Oleh karena itu, perlu adanya pengembangan sistem yang dapat membantu dalam menentukan penerima bantuan desa, yaitu berdasarkan kriteria yang telah ditentukan dan kemudian akan diproses dengan perhitungan menggunakan metode k-modes clustering. Metode k-modes merupakan hasil modifikasi dari metode k-means. Digunakan metode k-modes karena pada metode k-modes menggunakan data yang bertipe kategorikal sesuai dengan data penerima BLT di Desa Jatikerto, metode k-modes dapat menghasilkan cluster dengan proses yang lebih rinci, waktu komputasi untuk pembentukan cluster pada metode k-modes lebih singkat, dan metode kmodes unggul dalam mengelompokkan data yang berdimensi banyak. Sistem penentuan penerima BLT dibuat berbasis web untuk memudahkan admin atau pihak desa dalam mengakses sistem dimana saja.

\section{TINJAUAN PUSTAKA}

\subsection{Penelitian Terdahulu}

Pada penelitian Fithri dan Dicky dengan judul "Klasterisasi Penduduk Lanjut Usia Sumatera Selatan Menggunakan Algoritma K-Modes". Tujuan penelitian ini yaitu untuk memudahkan pemerintah menentukan kebijakan dan program khusus untuk kelompok (cluster) penduduk lansia. Adapaun persamaan dari penelitian yaitu sama-sama menggunakan metode $\mathrm{k}$-modes untuk mendapatkan hasil clustering dan yang menjadi perbedaan dengan system yang dibuat Fithri dan Dicky, adalah system yang dibuat Fithri dan Dicky menggunakan R-studio. [1]

Pada penelitian Fatma dan Irwan dengan judul "K-Modes Clustering Untuk Mengetahui Jenis Masakan Daerah Yang Populer Pada Website Resep Online (Studi Kasus: Masakan Banjar Di Cookpad.com)". Tujuan penelitian ini yaitu untuk mengelompokkan jenis makanan yang paling sering di posting oleh pengguna website recipe sharing. Adapun persamaan dari penelitian yaitu sama-sama 
menggunakan metode k-modes untuk mendapatkan hasil clustering. [2]

Pada penelitian Tanti dan Deden dengan judul "Implementasi Algoritma K-modes untuk Penentuan Prioritas Rehabilitasi Daerah Aliran Sungai Berdasarkan Parameter Lahan Kritis". Tujuan penelitian ini yaitu untuk menentukan DAS prioritas pada kawasan hutan lindung di Kabupaten Wonogiri dengan menggunakan lima parameter lahan kritis. Adapun persamaan dari penelitian yaitu sama-sama menggunakan metode k-modes untuk mendapatkan hasil clustering. [3]

Pada penelitian Nur berjudul "Analisis Cluster Non-Hirarki Dengan Menggunakan Metode K-Modes pada Mahasiswa Program Studi Statistika Angkatan 2015 FMIPA Universitas Mulawarman”. Tujuan penelitian ini yaitu untuk mengelompokkan mahasiswa berdasarkan pemilihan program studi statistika. Adapun persamaan dari penelitian yaitu sama-sama menggunakan metode k-modes untuk mendapatkan hasil clustering. [4]

Pada penelitian Sulton dengan judul "Klasifikasi Penentuan Penerima Bantuan Pangan Non Tunai Menggunakan Metode K-Means Clustering”. Tujuan penelitian ini yaitu mengembangkan sistem untuk mengelompokkan warga yang berhak menerima bantuan pangan non tunai (BPNT). Adapun persamaan dari penelitian yaitu sama-sama menggunakan studi kasus bantuan dan yang menjadi perbedaan dengan sistem yang dibuat Sulton, adalah system yang dibuat Sulton menggunakan metode kmeans dan berbasis desktop. [5]

\subsection{Bantuan Langsung Tunai (BLT)}

Bantuan Langsung Tunai Dana Desa (BLTDana Desa) adalah bantuan uang kepada keluarga miskin di desa yang bersumber dari Dana Desa untuk mengurangi dampak pandemi COVID-19. Adapun nilai BLT Dana Desa adalah Rp600.000 setiap bulan untuk setiap keluarga miskin yang memenuhi kriteria dan diberikan selama 3 (tiga) bulan dan Rp300.000 setiap bulan untuk tiga bulan berikutnya. BLT-Dana Desa ini bebas pajak. [12]

\subsection{Data Mining}

Data mining merupakan salah satu solusi untuk menjelaskan proses penggalian informasi dalam suatu basis data yang berskala besar dan proses pengelompokan otomatisasi kasus berdasarkan pola data yang diperoleh dari data set. Data mining dapat diterapkan pada berbagai bidang, dibagi menjadi empat kelompok : model prediksi (prediction modelling), analisis cluster (cluster analysis), analisis aosiasi (association analysis), dan deteksi anomaly (anomaly detection).[5]

\subsection{Algoritma K-Modes}

K-modes adalah hasil modifikasi dari algoritma k-means. K-means merupakan algoritma yang sangat handal dalam mengelompokan data besar tetapi $\mathrm{k}$ - means tidak bisa diterapkan pada data selain numerik. Pendekatan K-modes memodifikasi proses k-means standar untuk mengelompokan data dengan menganti fungsi jarak Euclidean dengan jarak simple matching dan menggunakan mode untuk mewakili pusat cluster. Selain itu k-modes menggunakan metode frekuensi untuk memperbaharui mode. [1]

K-modes melakukan modifikasi pada k-means sebagai berikut :

1. Menggunakan ukuran pencocokan ketidakmiripan sederhana pada fitur data bertipe kategorikal.

2. Mengganti mean cluster dengan modus (nilai yang paling sering muncul).

3. Menggunakan metode berbasis frekuensi untuk mencari modus dari sekumpulan nilai.

Berikut ini adalah langkah-langkah dalam clustering dengan k-modes :

1. Pilih $\mathrm{k}$ data sebagai inisialisasi centeroid (modus), satu untuk setiap klaster.

2. Hitung jarak antara masing-masing objek dan mode klaster, tetapkan objek ke klaster yang pusatnya memiliki jarak terdekat ke objek ulangi langkah ini sampai semua objek ditetapkan ke kelompok.

$\mathrm{D}(\mathrm{x}, \mathrm{y})=\sum \varepsilon(X j, Y j) r j=1$

Dimana :

$\mathrm{D}(\mathrm{x}, \mathrm{y})=$ jarak data $\mathrm{x}$ ke $\mathrm{y}$

$\mathrm{Xj}=$ nilai fitur ke-j dari $\mathrm{x}$

$\mathrm{Yj}=$ nilai fitur ke-j dari $\mathrm{y}$

$\mathrm{R}$ adalah jumlah fitur dan berikut adalah nilai pencocokan seperti pada persamaan berikut :

$$
\varepsilon(\mathrm{Xj}, \mathrm{Yj})=\left\{\begin{array}{lll}
0 & \mathrm{Xj}=\mathrm{Yj} \\
1 & \mathrm{Xj} \neq \mathrm{Yj}
\end{array}\right.
$$

3. Perbaharui modus (sebagai centroid) dari setiap klaster dengan nilai kategori yang sering muncul pada setiap klaster.

Ulangi langkah 2 dan 3 untuk memenuhi syarat, yaitu (a) data pada klaster tersebut tidak bergerak atau (b) posisi pusat centeroid tidak berubah. [3]

\section{METODE PENELITIAN}

\subsection{Perancangan Sistem}

Sistem proses penentuan penerima Bantuan Langsung Tunai (BLT) yang akan dibuat berbasis web dengan menggunakan metode K-Modes. Data yang digunakan adalah data penerima BLT Dana Desa Jatikerti Kec.Kromengan Kab.Malang. Diharapkan sistem yang dikembangkan dengan menerapkan metode K-Modes, dapat membantu pihak desa untuk menentukan golongan penerima BLT sehingga dapat mempersingkat waktu dalam penentuan penerima BLT dan mengolah data. Dengan demikian dapat menanggulangi kesalahan dalam menentukan penduduk yang layak menerima BLT.

\subsection{Blok Diagram Sistem}

Blok diagram adalah diagram dari sebuah sistem yang diwakili oleh blok dan dihubungkan dengan garis yang menunjukkan hubungan dari blok. Proses kerja pada pengelompokan data penduduk calon 
penerima BLT menggunakan metode $\mathrm{k}$-modes ditunjukan pada gambar 3.1

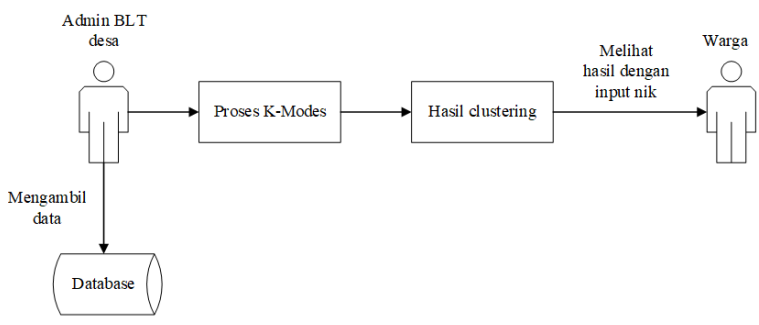

Gambar 3.1 Blok diagram sistem

Pada Gambar 3.1 blok diagram sistem proses penentuan penerima BLT database menyimpan semua data mentah yang belum diproses. Admin akan mengambil data mentah yang nantinya akan diproses menggunakan metode k-modes. Metode k-modes digunakan untuk mengelompokkan data penduduk yang layak menerima BLT. Pengelompokan data penduduk menggunakan tiga cluster yaitu sangat layak menerima BLT, layak menerima BLT, dan tidak layak menerima BLT. Warga dapat melihat hasil pengelompokan penerima BLT dengan menginpukan nik, dan akan ditampilkan data warga sesuai nik yang diinputkan.

\subsection{Struktur Menu}

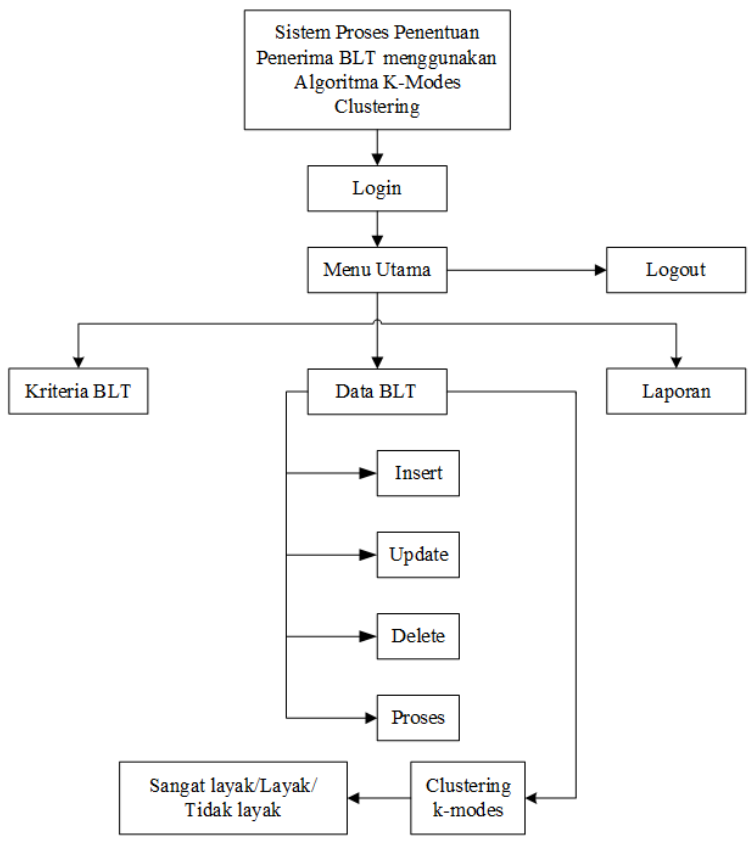

Gambar 3.2 Struktur menu

Pada Gambar 3.2 struktur menu sistem proses penentuan penerima BLT menggunakan algoritma kmodes clustering untuk masuk ke halaman utama admin BLT desa harus melakukan login dengan menginputkan username dan password. Jika benar maka admin akan masuk ke halaman menu admin, namun jika salah admin akan tetap di halaman login. Pada halaman admin, admin dapat melihat kriteria yang akan digunakan untuk proses penentuan BLT dana desa. Pada halaman menu admin, admin dapat melihat, menambah, mengedit, dan menghapus data BLT. Data BLT kemudian akan di kelompokkan menjadi tiga cluster yaitu sangat layak menerima BLT, layak menerima BLT, dan tidak layak menerima BLT.

\subsection{Flowchart Metode}

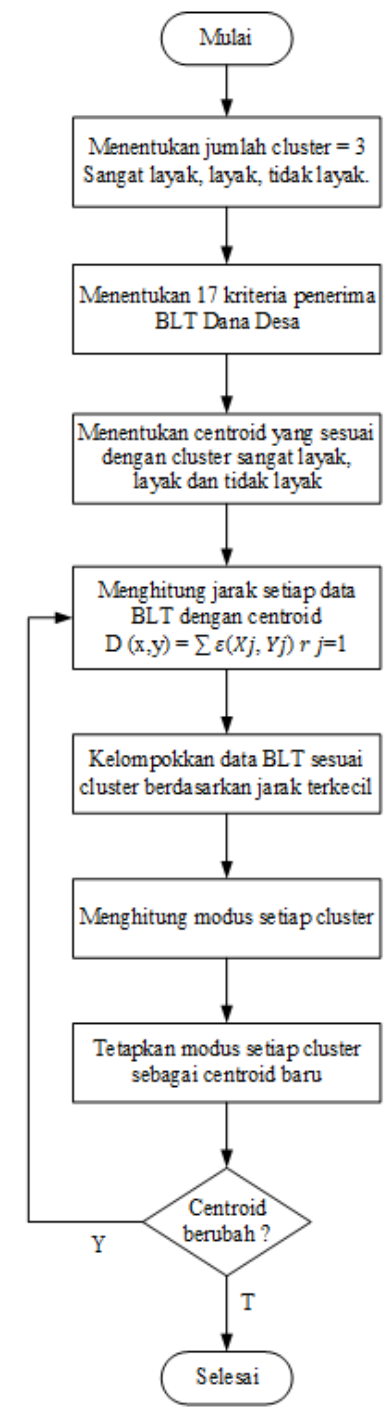

Gambar 3.3 Flowchart metode k-modes

Pada Gambar 3.3 Flowchart metode k-modes menjelaskan tentang alur dari metode k-modes yang diterapkan pada Sistem Proses Penentuan Penerima BLT. Alur metode dimulai menentukan tiga cluster yaitu sangat layak menerima BLT, layak menerima BLT dan tidak layak menerima BLT. Pengelompokan berdasarkan 17 kriteria. Setelah jumlah cluster di tentukan maka akan di lanjutkan dengan menentukan centroid, centroid awal ditentukan sendiri berdasarkan data yang memenuhi kriteria untuk setiap clusternya. Setelah menentukan centroidnya maka masuk ke proses menghitung jarak setiap data dengan centroid. Kemudian kelompokkan data berdasarkan jarak terkecil berdasarkan clusternya. Hasil yang di 
dapatkan dari perhitungan jarak akan di cari modus atau nilai yang paling sering muncul di setiap cluster untuk ditentukan sebagai centroid baru. Dimana pada anggota kelompok tiap cluster dibandingkan nilai apa saja yang sering muncul per atribut. Jika terdapat nilai yang sama maka diambil mana yang pertama ditemui. Setelah centroid baru didapatkan akan dilakukan pengecekan ada perubahan centroid atau tidak. Apabila ada perubahan centroid maka proses kembali ke langkah menghitung jarak setiap data pada centroid dengan menggunakan centroid baru untuk lanjut ke iterasi selanjutnya. Proses akan berhenti jika anggota pada iterasi sebelumnya bernilai sama atau tidak ada perubahan nilai sama sekali. Saat proses sudah berhenti akan didapatkan hasil clustering data penerima BLT.

\subsection{Flowchart Sistem}

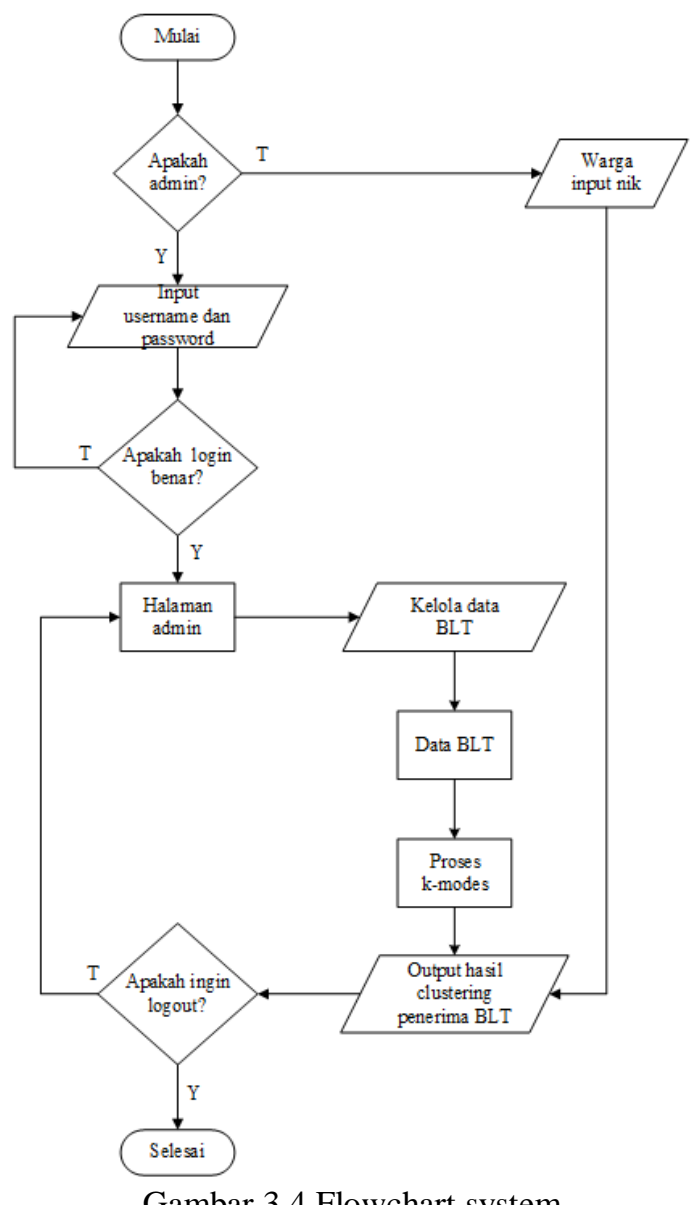

Gambar 3.4 Flowchart system

Pada Gambar 3.4 Flowchart sistem menjelaskan alur dari sistem yang dibuat. Jika yang masuk ke sistem adalah admin blt akan masuk ke halaman login admin blt, namun jika yang masuk warga akan masuk ke halaman hasil user. Di halaman login admin blt melakukan login dengan menginputkan username dan password, login akan dicek dahulu apakah username dan password yang diinputkan sudah benar. Jika benar maka admin blt akan masuk ke halaman menu admin, namun jika salah admin akan tetap di halaman login. Pada halaman menu admin, admin dapat melakukan kelola data BLT. Data BLT akan dikelompokkan sesuai 17 kriteria menggunakan metode k-modes clustering. Hasil dari proses clustering penerima BLT dalam bentuk report yang dapat didownload. Apabila proses yang dilakukan admin sudah selesai, admin dapat logout dan proses selesai. Di halaman hasil user warga dapat melihat hasil pengelompokan penerima BLT dengan menginpukan nik, dan akan ditampilkan data warga sesuai nik yang diinputkan.

\section{HASIL DAN PEMBAHASAN 4.1. Halaman dashboard}

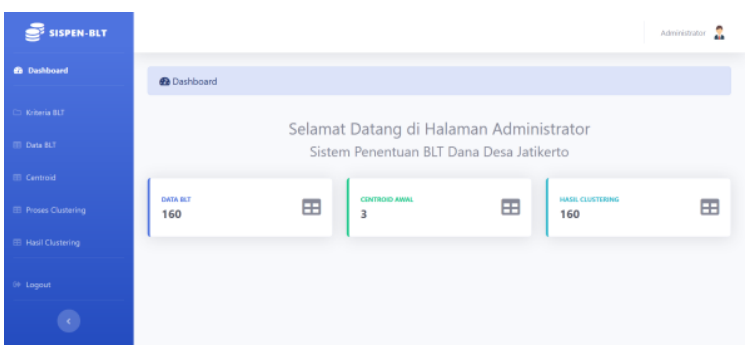

Gambar 4.1 Tampilan halaman dashboard

Pada Gambar 4.1 merupakan halaman dashboard yang berisi menu - menu dan total data BLT, data centroid, dan data hasil clustering pada sistem penentuan penerima BLT.

\subsection{Halaman kriteria}

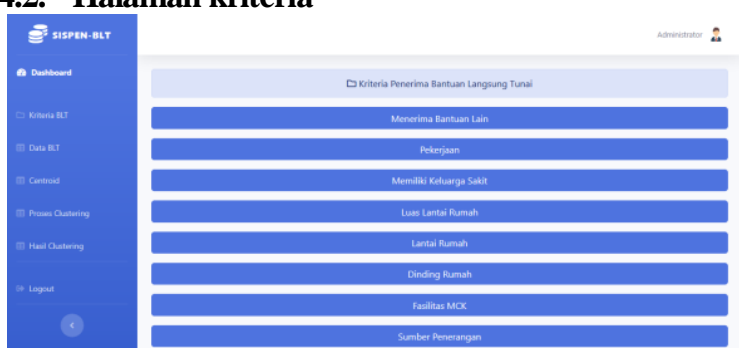

Gambar 4.2 Tampilan halaman kriteria

Pada Gambar 4.2 merupakan halaman kriteria yang berisi sebuah button untuk menampilkan halaman setiap kriteria.

\subsection{Halaman data BLT}

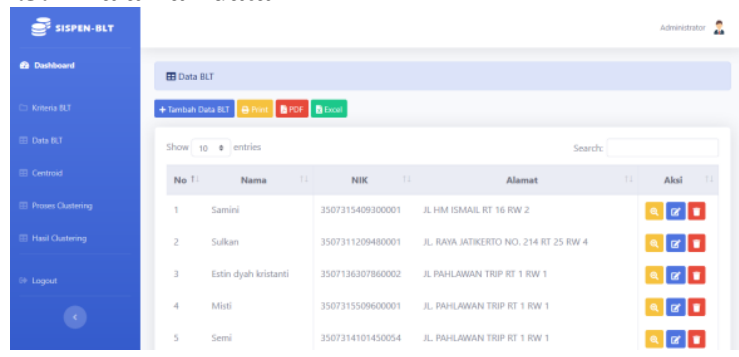

Gambar 4.3 Tampilan halaman data BLT 
Pada Gambar 4.3 merupakan halaman data BLT yang berisi sebuah tabel untuk menampilkan data BLT.

\subsection{Halaman centroid}

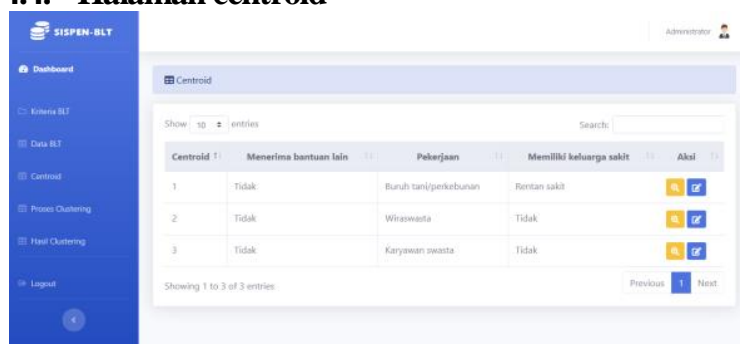

Gambar 4.4 Tampilan halaman data centroid

Pada Gambar 4.4 merupakan halaman data centroid yang berisi sebuah tabel untuk menampilkan data centroid.

\subsection{Halaman hasil clustering k-modes}
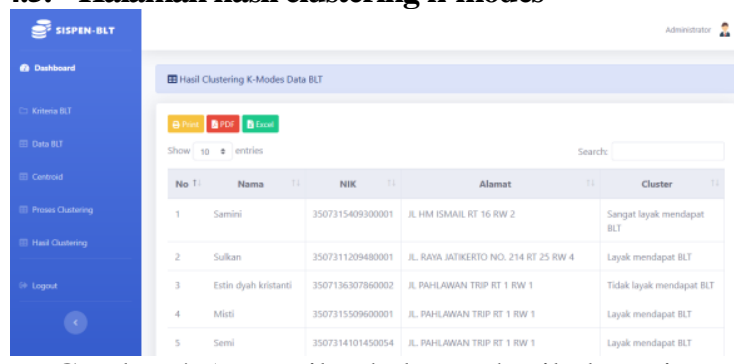

Gambar 4.5 Tampilan halaman hasil clustering

Pada Gambar 4.5 merupakan halaman hasil clustering k-modes yang akan menampilkan hasil clustering penerima BLT.

\subsection{Halaman cek penerima BLT}

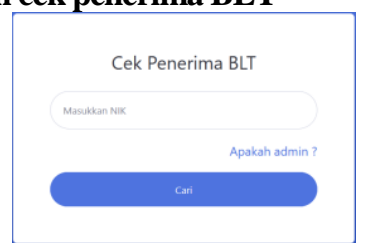

Gambar 4.6 Tampilan halaman cek penerima BLT

Pada Gambar 4.6 merupakan halaman cek penerima BLT yang akan menampilkan hasil cluster setiap nik sesuai denan nik yang diinputkan oleh user warga.

\subsection{Implementasi Metode K-Modes}

Clustering menggunakan metode k-modes bertujuan untuk mengelompokkan data yang berkarakteristik sama dalam satu cluster dan data dengan karakteristik berbeda ke dalam cluster yang lain. Berdasarkan data BLT yang digunakan terdapat beberapa kriteria yaitu tidak menerima bantuan lain, pekerjaan, menerima bantuan lain, luas lantai rumah, lantai rumah, dinding rumah, mck, sumber penerangan, sumber air minum, bahan bakar memasak, konsumsi, pakaian, makan, kesanggupan berobat, penghasilan, pendidikan, aset.

\subsection{Menentukan jumlah cluster dan centroid awal}

Tahap awal perhitungan data menggunakan metode k-modes adalah dengan menentukan jumlah $\mathrm{k}$ cluster yang akan dibentuk. Jumlah kluster yang digunakan adalah 3, kemudian dilakukan penentuan centroid awal.

Tabel 4.1 Centroid awal

\begin{tabular}{|c|c|c|c|c|c|c|c|c|}
\hline Centroid & K1 & $\mathbf{K 2}$ & $\mathbf{K 3}$ & $\mathbf{K 4}$ & $\mathbf{K 5}$ & $\mathbf{K 6}$ & .. & K17 \\
\hline 1 & Tidak & $\begin{array}{c}\text { Buruh } \\
\text { tani/perkebunan }\end{array}$ & $\begin{array}{c}\text { Rentan } \\
\text { sakit }\end{array}$ & $\begin{array}{c}<8 \mathrm{~m} 2 \\
\text { /orang }\end{array}$ & Tanah & Bambu & .. & $\begin{array}{c}\text { Tidak } \\
\text { memiliki }\end{array}$ \\
\hline 2 & Tidak & Wiraswasta & Tidak & $\begin{array}{c}<8 \mathrm{~m} 2 \\
\text { /orang }\end{array}$ & Semen & $\begin{array}{c}\text { Tembok } \\
\text { tanpa plester }\end{array}$ & .. & Memiliki \\
\hline 3 & Tidak & $\begin{array}{c}\text { Karyawan } \\
\text { swasta }\end{array}$ & Tidak & $\begin{array}{c}>9 \mathrm{~m} 2 \\
\text { /orang }\end{array}$ & Ubin & $\begin{array}{c}\text { Tembok } \\
\text { halus }\end{array}$ &.. & Memiliki \\
\hline
\end{tabular}

Pada Tabel 4.1 adalah centroid awal, centroid ditentukan sebanyak jumlah cluster. Penentuan centroid awal menggunakan tiga data yang kriterianya memenuhi untuk digunakan sebagai centroid satu, centroid dua dan centroid tiga Centroid satu digunakan untuk cluster sangat layak mendapatkan BLT, centroid dua digunakan untuk cluster layak mendapatkan BLT, dan centroid ketiga digunakan untuk cluster tidak layak mendapatkan BLT.

4.9. Menghitung jarak data dengan centroid dan mengelompokkan berdasarkan cluster

Menghitung jarak setiap data dengan centroid menggunakan persamaan simple matching. Pada persamaan simple matcing jika data sama dengan centroid maka bernilai 0 , sedangkan jika data tidak sama dengan centroid maka bernilai 1 .

$\mathrm{D}\left(\mathrm{x}_{1}, \mathrm{c}_{1}\right)$ :

$=\varepsilon\left(x_{1}, 1, c_{1}, 1\right)+\varepsilon\left(x_{1}, 2, c 1,2\right)+\varepsilon\left(x_{1}, 3, c 1,3\right)$

$+\varepsilon\left(x_{1}, 4, c_{1}, 4\right)+\varepsilon\left(x_{1}, 5, c 1,5\right)+\varepsilon\left(x_{1}, 6, c 1\right.$,

$6)+\varepsilon\left(x_{1}, 7, c_{1}, 7\right)+\varepsilon\left(x_{1}, 8, c_{1}, 8\right)+\varepsilon\left(x_{1}, 9, c_{1}\right.$,

$9)+\varepsilon\left(x_{1}, 10, c_{1}, 10\right)+\varepsilon\left(x_{1}, 11, c_{1}, 11\right)+\varepsilon\left(x_{1}\right.$,

$\left.12, c_{1}, 12\right)+\varepsilon\left(x_{1}, 13, c_{1}, 13\right)+\varepsilon\left(x_{1}, 14, c_{1}, 14\right)$

$+\varepsilon\left(x_{1}, 15, c_{1}, 15\right)+\varepsilon\left(x_{1}, 16, c_{1}, 16\right)+\varepsilon\left(x_{1}\right.$,

$\left.17, c_{1}, 17\right)$

$=($ tidak, tidak $)+($ buruh tani/perkebunan, buruh tani/perkebunan $)+($ rentan sakit, rentan sakit $)+$ (<8m2/orang, $<8 \mathrm{~m} 2 /$ orang $)+($ tanah, tanah $)$ $+($ bambu, bambu $)+($ memiliki, memiliki $)+$ 
(listrik , listrik) + (sumur, sumur) + (kayu bakar

, kayu bakar $)+(>1 \mathrm{kali} / \mathrm{minggu},>1 \mathrm{kali} / \mathrm{minggu})$

$+(1$ stel/tahun, $1 \mathrm{stel} /$ tahun $)+(>2 \mathrm{kali} /$ hari,

$>2 \mathrm{kali} /$ hari $)+($ tidak, tidak $)+(<600 \mathrm{rb} / \mathrm{bulan}$

$<600 \mathrm{rb} /$ bulan $)+($ tamat sd/sederajat, tamat

$\mathrm{sd} /$ sederajat $)+($ tidak memiliki, tidak memiliki)

$=0+0+0+0+0+0+0+0+0+0+0+0+0$

$+0+0+0+0=0$

Selanjutnya perhitungan jarak data dengan centroid dilakukan untuk data ke-2 sampai data terakhir. Hasil perhitungan jarak data dengan centroid di tunjukkan pada Tabel 4.2.

\subsection{Mencari modus setiap cluster}

Langkah berikutnya adalah mencari modus atau nilai yang paling sering muncul pada setiap cluster untuk menentukan centroid baru

Tabel 4.3 Modus cluster 1 iterasi 1

\begin{tabular}{|c|c|c|c|c|c|c|c|c|}
\hline No & K1 & K2 & K3 & $\mathbf{K 4}$ & $\mathbf{K 5}$ & K6 & .. & K17 \\
\hline 1 & Tidak & $\begin{array}{c}\text { Buruh } \\
\text { tani/perkebunan }\end{array}$ & $\begin{array}{c}\text { Rentan } \\
\text { sakit }\end{array}$ & $\begin{array}{c}<8 \mathrm{~m} 2 \\
\text { /orang }\end{array}$ & Tanah & Bambu &.. & $\begin{array}{c}\text { Tidak } \\
\text { memiliki }\end{array}$ \\
\hline 2 & Tidak & $\begin{array}{c}\text { Mengurus rumah } \\
\text { tangga }\end{array}$ & Tidak & $\begin{array}{c}<8 \mathrm{~m} 2 \\
\text { /orang }\end{array}$ & Tanah & Bambu &.. & $\begin{array}{c}\text { Tidak } \\
\text { memiliki }\end{array}$ \\
\hline 3 & Tidak & Buruh harian lepas & $\begin{array}{c}\text { Sakit } \\
\text { menahun }\end{array}$ & $\begin{array}{c}<8 \mathrm{~m} 2 \\
\text { /orang }\end{array}$ & Tanah & Kayu murah &.. & $\begin{array}{c}\text { Tidak } \\
\text { memiliki }\end{array}$ \\
\hline Modus & Tidak & $\begin{array}{c}\text { Buruh } \\
\text { tani/perkebunan }\end{array}$ & Tidak & $\begin{array}{c}<8 \mathrm{~m} 2 \\
\text { /orang }\end{array}$ & Tanah & Bambu &.. & $\begin{array}{c}\text { Tidak } \\
\text { memiliki }\end{array}$ \\
\hline
\end{tabular}

Pada Tabel 4.3 merupakan hasil pencarian modus pada cluster satu. Dimana pada cluster satu didapatkan frekuensi data yang paling sering muncul yang akan digunakan sebagai centroid baru cluster satu.

Tabel 4.4 Modus cluster 2 iterasi 1

\begin{tabular}{|c|c|c|c|c|c|c|c|c|c|}
\hline No & K1 & K2 & K3 & K4 & K5 & K6 & K7 & .. & K17 \\
\hline 1 & Tidak & Wiraswasta & Tidak & $\begin{array}{c}<8 \mathrm{~m} 2 \\
\text { /orang }\end{array}$ & Semen & $\begin{array}{c}\text { Tembok tanpa } \\
\text { plester }\end{array}$ & Memiliki & .. & Memiliki \\
\hline Modus & Tidak & Wiraswasta & Tidak & $\begin{array}{c}<8 \mathrm{~m} 2 \\
/ \text { orang }\end{array}$ & Semen & $\begin{array}{c}\text { Tembok tanpa } \\
\text { plester }\end{array}$ & Memiliki &.. & Memiliki \\
\hline
\end{tabular}

Pada Tabel 4.4 merupakan hasil pencarian modus pada cluster dua. Dimana pada cluster dua didapatkan frekuensi data yang paling sering muncul yang akan digunakan sebagai centroid baru cluster dua.

Tabel 4.5 Modus cluster 3 iterasi 1

\begin{tabular}{|c|c|c|c|c|c|c|c|c|c|}
\hline No & K1 & K2 & K3 & $\mathbf{K 4}$ & K5 & K6 & K7 & .. & K17 \\
\hline 1 & Tidak & $\begin{array}{c}\text { Karyawan } \\
\text { swasta }\end{array}$ & Tidak & $\begin{array}{c}>9 \mathrm{~m} 2 \\
\text { /orang }\end{array}$ & Ubin & Tembok halus & Memiliki & .. & Memiliki \\
\hline Modus & Tidak & $\begin{array}{c}\text { Karyawan } \\
\text { swasta }\end{array}$ & Tidak & $\begin{array}{c}>9 \mathrm{~m} 2 \\
\text { /orang }\end{array}$ & Ubin & Tembok halus & Memiliki & .. & Memiliki \\
\hline
\end{tabular}

Pada Tabel 4.5 merupakan hasil pencarian modus pada cluster tiga. Dimana pada cluster tiga didapatkan frekuensi data yang paling sering muncul yang akan digunakan sebagai centroid baru cluster tiga.

\subsection{Centroid baru}

Tabel 4.6 Centroid baru

\begin{tabular}{|c|c|c|c|c|c|c|c|c|}
\hline Centroid & K1 & K2 & K3 & K4 & K5 & K6 &.. & K17 \\
\hline 1 & Tidak & $\begin{array}{c}\text { Buruh } \\
\text { tani/perkebunan }\end{array}$ & Tidak & $\begin{array}{l}<8 \mathrm{~m} 2 \\
\text { /orang }\end{array}$ & Tanah & Bambu & .. & $\begin{array}{c}\text { Tidak } \\
\text { memiliki }\end{array}$ \\
\hline 2 & Tidak & Wiraswasta & Tidak & $\begin{array}{l}<8 \mathrm{~m} 2 \\
\text { /orang }\end{array}$ & Semen & $\begin{array}{c}\text { Tembok tanpa } \\
\text { plester }\end{array}$ & .. & Memiliki \\
\hline 3 & Tidak & Karyawan swasta & Tidak & $\begin{array}{l}>9 \mathrm{~m} 2 \\
\text { /orang }\end{array}$ & Ubin & Tembok halus & .. & Memiliki \\
\hline
\end{tabular}


Pada Tabel 4.6 merupakan centroid baru. Centroid baru didapatkan dari frekuensi data yang paling sering muncul atau modus setiap cluster. Setelah centroid baru didapatkan akan dilakukan pengecekan centroid baru dengan centroid awal atau centroid sebelumnya. Jika centroid berubah akan kembali ke langkah mengitung jarak dengan data, sedangkan jika centroid tetap maka proses akan berhenti dan hasil clustering penerima BLT didapatkan.

\subsection{Pengujian Sistem}

Perbandingan data lama dengan sistem dilakukan dengan membandingkan cluster dengan data lama atau pengelompokan secara manual dengan sistem yang menerapkan metode $k$-modes clustering. Pengujian ini menggunakan 160 data yang dikelompokkan menjadi 3 cluster, sangat layak, layak dan tidak layak.

Tabel 4.7 Pengujian Sistem

\begin{tabular}{|c|c|c|c|c|}
\hline \multirow{2}{*}{ No } & \multirow{2}{*}{ Nama } & \multicolumn{2}{|c|}{ Hasil Clustering } & \multirow{2}{*}{ Keterangan } \\
\cline { 3 - 4 } & & Manual & Sistem & \\
\hline 1 & Samini & SL & SL & Hasil sama \\
\hline 2 & Sulkan & L & L & Hasil sama \\
\hline 3 & Estin & TL & TL & Hasil sama \\
\hline 4 & Misti & SL & L & Hasil berbeda \\
\hline 5 & Semi & SL & L & Hasil berbeda \\
\hline.. &.. &.. &.. & Hasil sama \\
\hline 160 & Suyoto & TL & TL & H \\
\hline
\end{tabular}

Berdasarkan perbandingan data clustering manual dengan clustering sistem diatas, pengujian sistem dilakukan dengan menggunakan 160 data yang dapat dilihat dengan presentase pengujiannya sebagai berikut :

$$
\begin{aligned}
& \text { Pengujian Sistem }=\frac{\text { banyak hasil pengujian benar }}{\text { banyak data training }} \times 100 \% \\
& =\frac{\mathbf{1 5 5}}{\mathbf{1 6 0}} \times \mathbf{1 0 0} \%=\mathbf{9 6 , \mathbf { 8 7 5 }} \%
\end{aligned}
$$

Berdasarkan Tabel 4.7 pengujian sistem dari total 160 data yang digunakan untuk membandingkan clustering manual dengan clustering sistem adalah 155 data memiliki hasil sama dan 5 data memiliki hasil berbeda. Didapatkan nilai presentase pengujian sistem sebesar 96,875\% yang berarti hasil yang ditunjukkan dari pengujian sistem adalah baik.

\subsection{Pengujian Sistem Error}

Pengujian sistem error dilakukan dengan membandingkan nilai jarak yang didapatkan data perhitungan excel metode $k$-modes clustering dengan sistem yang menerapkan metode $k$-modes clustering. yang dikelompokkan menjadi 3 cluster, sangat layak, layak dan tidak layak.

Tabel 4.8 Pengujian Sistem Error

\begin{tabular}{|c|c|c|c|c|c|c|c|c|c|c|c|}
\hline \multirow{2}{*}{ No } & \multicolumn{9}{|c|}{ Manual } & \multicolumn{9}{c|}{ Sistem } & \multirow{2}{*}{ Error } \\
\cline { 2 - 14 } & $\mathbf{d}(\mathbf{x i}, \mathbf{c 1})$ & $\mathbf{d}(\mathbf{x i , c 2})$ & $\mathbf{d}(\mathbf{x 1 , c 3 )}$ & Min & $\mathbf{C}$ & $\mathbf{d}(\mathbf{x i}, \mathbf{c 1})$ & $\mathbf{d}(\mathbf{x i}, \mathbf{c 2})$ & $\mathbf{d}(\mathbf{x 1 , c 3 )}$ & Min & C & \\
\hline 1 & 3 & 8 & 11 & 3 & SL & 3 & 8 & 11 & 3 & SL & $0 \%$ \\
\hline 2 & 7 & 3 & 6 & 3 & L & 7 & 3 & 6 & 3 & L & $0 \%$ \\
\hline 3 & 8 & 8 & 1 & 1 & TL & 8 & 8 & 1 & 1 & TL & $0 \%$ \\
\hline 4 & 4 & 3 & 9 & 3 & L & 4 & 3 & 9 & 3 & L & $0 \%$ \\
\hline 5 & 6 & 5 & 10 & 5 & L & 6 & 5 & 10 & 5 & L & $0 \%$ \\
\hline.. &.. &.. &.. &.. &.. &.. &.. &.. &.. &.. &.. \\
\hline 160 & 8 & 8 & 0 & 0 & TL & 8 & 8 & 0 & 0 & TL & $0 \%$ \\
\hline
\end{tabular}

Keterangan :

$\begin{array}{ll}\text { Min } & \text { : Minimum } \\ \text { C } & \text { : Cluster } \\ \text { SL } & \text { : Sangat Layak } \\ \text { L } & \text { : Layak } \\ \text { TL } & \text { : Tidak Layak }\end{array}$

Pengujian sistem error dilakukan dengan menggunakan 160 data yang dapat dilihat dengan presentase pengujiannya sebagai berikut :

$$
\begin{aligned}
& =\frac{\text { perhitungan sistem }- \text { perhitungan manual }}{\text { perhitungan manual }} \times 100 \% \\
& =\frac{\mathbf{1 6 0}-\mathbf{1 6 0}}{\mathbf{1 6 0}} \times \mathbf{1 0 0} \%=\mathbf{0} \%
\end{aligned}
$$

Berdasarkan Tabel 4.8 pengujian sistem dari total 160 data yang digunakan untuk membandingkan nilai jarak yang didapatkan data perhitungan excel metode $k$-modes clustering dengan sistem yang menerapkan metode $k$-modes clustering. Dari pengujian sistem error diatas dapat disimpulkan bahwa data ke-1 sampai data ke-160 diperoleh tingkat eror adalah $0 \%$ yang berarti perhitungan pada program berjalan $100 \%$ sesuai dengan perhitungan tanpa error.

\subsection{Pengujian Fungsional}

Pengujian fungsional sistem dilakukan untuk menguji fitur-fitur yang ada pada sistem clustering penentuan penerima bantuan langsung tunai. Pengujian browser menu website dilakukan menggunakan 3 browser yaitu Microsoft Edge (v.87.0), Google Chrome (v.86.0) dan Mozilla Firefox (v.83.0). Hasil pengujian ditunjukkan pada Tabel 4.9.

Tabel 4.9 Pengujian Fungsional

\begin{tabular}{|c|l|c|c|c|}
\hline \multirow{2}{*}{ NO } & \multirow{2}{*}{ Aspek pengujian } & \multicolumn{3}{|c|}{ Nama Browser } \\
\cline { 3 - 5 } & & ME & GC & MF \\
\hline 1. & Halaman login & $\checkmark$ & $\checkmark$ & $\checkmark$ \\
\hline 2. & Halaman data kriteria & $\checkmark$ & $\checkmark$ & $\checkmark$ \\
\hline 3. & Halaman data BLT & $\checkmark$ & $\checkmark$ & $\checkmark$ \\
\hline 4. & Input data BLT & $\checkmark$ & $\checkmark$ & $\checkmark$ \\
\hline 5. & Edit data BLT & $\checkmark$ & $\checkmark$ & $\checkmark$ \\
\hline
\end{tabular}




\begin{tabular}{|c|l|c|c|c|}
\hline \multirow{2}{*}{ NO } & \multirow{2}{*}{ Aspek pengujian } & \multicolumn{3}{|c|}{ Nama Browser } \\
\cline { 3 - 5 } & & ME & GC & MF \\
\hline 6. & Detail data BLT & $\checkmark$ & $\checkmark$ & $\checkmark$ \\
\hline 7. & Halaman proses k-modes & $\checkmark$ & $\checkmark$ & $\checkmark$ \\
\hline 8. & Halaman hasil clustering & $\checkmark$ & $\checkmark$ & $\checkmark$ \\
\hline 9. & Fitur export pdf data BLT & $\checkmark$ & $\checkmark$ & $\checkmark$ \\
\hline 10. & Fitur export excel data BLT & $\checkmark$ & $\checkmark$ & $\checkmark$ \\
\hline 11. & Fitur export pdf hasil clustering & $\checkmark$ & $\checkmark$ & $\checkmark$ \\
\hline 12. & $\begin{array}{l}\text { Fitur export excel hasil } \\
\text { clustering }\end{array}$ & $\checkmark$ & $\checkmark$ & $\checkmark$ \\
\hline 13. & Logout & $\checkmark$ & $\checkmark$ & $\checkmark$ \\
\hline 14. & Halaman cek hasil BLT & $\checkmark$ & $\checkmark$ & $\checkmark$ \\
\hline
\end{tabular}

Keterangan :

$\checkmark=$ Berjalan

$\mathrm{X}=$ Tidak berjalan

Berdasarkan hasil pengujian terhadap sistem yang telah dirancang dengan menggunakan browser Microsoft Edge, Google Chrome dan Mozzilla Firefox. sistem berfungsi dengan baik terhadap ketiga browser tersebut.

\subsection{Pengujian user admin}

Berdasarkan pengujian user admin yang dilakukan oleh dua responden sebagai admin yang mengelola dana bantuan untuk menguji aspek kepuasan user terhadap tampilan, kemudahan pengguna, kelengkapan fitur dan manfaat sistem. Hasil pengujian user admin ditunjukkan pada Table 4.10 .

Tabel 4.10 Pengujian user admin

\begin{tabular}{|c|c|c|c|c|c|}
\hline \multirow{2}{*}{ No } & \multirow{2}{*}{ Pertanyaan } & \multicolumn{4}{|c|}{ Hasil uji } \\
\hline & & SS & $\mathbf{S}$ & KS & TS \\
\hline 1. & $\begin{array}{l}\text { Apakah tampilan } \\
\text { dari sistem proses } \\
\text { penentuan } \\
\text { penerima BLT ini } \\
\text { terlihat menarik? }\end{array}$ & & 2 & & \\
\hline 2. & $\begin{array}{l}\text { Apakah sistem } \\
\text { proses penentuan } \\
\text { penerima BLT ini } \\
\text { mudah digunakan } \\
?\end{array}$ & 1 & 1 & & \\
\hline 3. & $\begin{array}{l}\text { Apakah sistem } \\
\text { proses penentuan } \\
\text { penerima BLT ini } \\
\text { memiliki fitur } \\
\text { yang lengkap? }\end{array}$ & & 2 & & \\
\hline 4. & $\begin{array}{l}\text { Apakah sistem } \\
\text { proses penentuan } \\
\text { penerima BLT ini } \\
\text { memudahkan } \\
\text { admin blt desa } \\
\text { menentukan } \\
\text { penerima BLT? }\end{array}$ & 1 & 1 & & \\
\hline Prese & & $25 \%$ & $75 \%$ & & \\
\hline
\end{tabular}

Keterangan :

$\begin{array}{ll}\text { SS } & \text { : Sangat setuju } \\ \text { S } & \text { : Setuju } \\ \text { KS } & \text { : Kurang setuju } \\ \text { TS } & \text { : Tidak setuju }\end{array}$

Berdasarkan Tabel 4.10 Hasil pengujian dijabarkan dengan rumus sebagai berikut :

\section{$\frac{\text { Total skor perkolom }}{\text { total skor keseluruhan }} \times 100 \%$}

Perhitungan presentase penilaian untuk 4 pertanyaan kepada 2 responden sebagai berikut :

Sangat setuju $=\frac{2}{8} \times 100 \%=75 \%$

Setuju $=\frac{6}{8} \times 100 \%=75 \%$

Pada pengujian kepuasan pengguna diambil hasil bahwa dari 2 user admin yang telah diambil kuisioner memberikan presentase $25 \%$ sangat setuju dan $75 \%$ setuju dengan website sistem penentuan penerima BLT.

\subsection{Pengujian user warga}

Berdasarkan pengujian user warga yang dilakukan oleh enam responden yaitu warga Desa Jatikerto sebagai pengguna sistem untuk menguji aspek kepuasan user terhadap tampilan, kemudahan pengguna, kelengkapan fitur dan manfaat sistem. Hasil pengujian user warga ditunjukkan pada Table 4.11.

Tabel 4.11 Pengujian user warga

\begin{tabular}{|c|c|c|c|c|c|}
\hline \multirow{2}{*}{ No } & \multirow{2}{*}{ Pertanyaan } & \multicolumn{4}{|c|}{ Hasil uji } \\
\hline & & SS & $\mathbf{S}$ & KS & TS \\
\hline 1. & $\begin{array}{l}\text { Apakah tampilan } \\
\text { dari sistem } \\
\text { pengecekan } \\
\text { penerima BLT ini } \\
\text { terlihat menarik? }\end{array}$ & & 6 & & \\
\hline 2. & $\begin{array}{l}\text { Apakah sistem } \\
\text { pengecekan } \\
\text { penerima BLT ini } \\
\text { mudah digunakan } \\
\text { ? }\end{array}$ & & 6 & & \\
\hline 3. & $\begin{array}{l}\text { Apakah sistem } \\
\text { pengecekan } \\
\text { penerima BLT ini } \\
\text { memiliki fitur } \\
\text { yang lengkap? }\end{array}$ & & 5 & 1 & \\
\hline 4. & $\begin{array}{l}\text { Apakah sistem } \\
\text { pengecekan } \\
\text { penerima BLT ini } \\
\text { memudahkan } \\
\text { pengguna melihat } \\
\text { hasil penerima } \\
\text { BLT? }\end{array}$ & 2 & 4 & & \\
\hline \multicolumn{2}{|c|}{ Presentase } & $8,3 \%$ & $\begin{array}{c}87,5 \\
\%\end{array}$ & $4,2 \%$ & \\
\hline
\end{tabular}

Keterangan :

SS : Sangat setuju

S : Setuju

KS : Kurang setuju

TS : Tidak setuju

Berdasarkan Tabel 4.11 Hasil pengujian dijabarkan dengan rumus sebagai berikut :

$\frac{\text { Total skor perkolom }}{\text { total skor keseluruhan }} \times 100 \%$

Perhitungan presentase penilaian untuk 4 pertanyaan kepada 6 responden sebagai berikut :

Sangat setuju $=\frac{2}{24} \times 100 \%=8,3 \%$

Setuju $=\frac{21}{24} \times 100 \%=87,5 \%$ 
Kurang setuju $=\frac{1}{24} \times 100 \%=4,2 \%$

Pada pengujian kepuasan pengguna diambil hasil bahwa dari 6 user warga yang telah diambil kuisioner memberikan presentase 8,3\% sangat setuju , $87,5 \%$ setuju dan $4,2 \%$ kurang setuju dengan website sistem penentuan penerima BLT.

\section{KESIMPULAN DAN SARAN}

\subsection{Kesimpulan}

Berikut ini adalah kesimpulan yang dapatkan setelah melakukan pembuatan aplikasi Sistem Penentuan Penerima Bantuan Langsung Tunai (BLT) menggunakan metode clustering k-modes adalah sebagai berikut :

1. Sistem penentuan penduduk penerima Bantuan Langsung Tunai (BLT) berbasis website dibuat untuk mempermudah admin dalam mengelola data BLT dan mempermudah user warga melihat hasil clustering.

2. Hasil dari perbandingan pengujian sistem clustering manual dengan sistem dari 15 data awal yang diuji didapatkan nilai 93,3\%, sedangkan dari 160 data yang diuji didapatkan nilai $96,875 \%$.

3. Hasil dari perbandingan pengujian sistem error manual dengan sistem menggunakan nilai jarak dari 15 data awal yang diuji dan dari 160 data didapatkan nilai error $0 \%$

4. Hasil dari pengujian fungsional fitur login, crud kriteria BLT, crud data BLT, proses clustering, hasil clustering, print, export pdf, export excel, logout, dan sek hasil BLT semuanya dapat berjalan baik.

5. Hasil dari pengujian system dapat berjalan baik pada Microsoft Edge (v.87.0), Google Chrome (v.86.0) dan Firefox Browser (v.83.0).

6. Hasil dari pengujian user admin dari 2 responden $25 \%$ menyatakan sangat setuju dan $75 \%$ menyatakan setuju.

7. Hasil dari pengujian user warga dari 6 responden menyatakan $8,3 \%$ sangat setuju, $87,5 \%$ setuju dan 4,2\% kurang setuju.

8. Hasil clustering sangat layak, layak dan tidak layak akan digunakan untuk memprioritaskan penduduk penerima BLT.

\subsection{Saran}

Berdasarkan penelitian yang telah dilakukan, maka penulis dapat memberikan saran-saran untuk pengembangan selanjutnya antar lain:

1. Sistem clustering penentuan penerima BLT menggunakan metode $k$-modes clustering dilakukan perbandingan dengan metode clustering yang lain.

2. Dalam pengembangan sistem selanjutnya, sistem ini dapat di ubah menjadi sistem penentuan penerima BLT berbasis desktop.

\section{DAFTAR PUSTAKA}

[1] Fithri Selva Jumeilah, D. P. (2017). KLASTERISASI PENDUDUK LANJUT USIA SUMATERA SELATAN MENGGUNAKAN ALGORITMA K-MODES. Jurnal TAM (Technology Acceptance Model) Volume 8, No2, Desember 2017.

[2] Fatma Indriani, I. B. (2017). K-MODES CLUSTERING UNTUK MENGETAHUI JENIS MASAKAN DAERAH YANG POPULER PADA WEBSITE RESEP ONLINE (STUDI KASUS: MASAKAN BANJAR DI COOKPAD.COM). Jurnal Teknologi Informasi dan Ilmu Komputer (JTIIK).

[3] Tanti Yulianita, D. I. (2017). Implementasi Algoritma K-modes untuk Penentuan Prioritas Rehabilitasi Daerah Aliran Sungai Berdasarkan Parameter Lahan Kritis.

[4] Nur Amah, S. W. (2017). Analisis Cluster NonHirarki Dengan Menggunakan Metode KModes pada Mahasiswa Program Studi Statistika Angkatan 2015 FMIPA Universitas Mulawarman. Jurnal EKSPONENSIAL.

[5] Pratama, S. G. (2019). KLASIFIKASI PENENTUAN PENERIMA BANTUAN PANGAN NON TUNAI MENGGUNAKAN METODE K-MEANS CLUSTERING. JATI (Jurnal Mahasiswa Teknik Informatika).

[6] Efraim Harpendi Bara, Y. A. (2020). PENGELOMPOKAN DATA OBAT MENGGUNAKAN METODE K-MEANS. JATI (Jurnal Mahasiswa Teknik Informatika).

[7] Muhammad Hafiz Azhar, P. P. (2018). Analisis Sentimen pada Ulasan Hotel dengan Fitur Score Representation dan Identifikasi Aspek pada Ulasan Menggunakan K-Modes. Jurnal Pengembangan Teknologi Informasi dan Ilmu Komputer.

[8] Ahmad Badruttamam, ,. S. (2020). PENERAPAN ANALISIS KLASTER KMODES DENGAN VALIDASI DAVIES BOULDIN INDEX DALAM MENENTUKAN KARAKTERISTIK KANAL YOUTUBE DI INDONESIA. JURNAL GAUSSIAN.

[9] Khalid, H. T. (2012). Klasterisasi Data Kategorikal Berbasis Fuzzy K-Modes Dan Artificial Bee Colony.

[10] Prasetyo, E. (2014). Data Mining Mengolah Data Menjadi Informasi Menggunakan Matlab. Yogyakarta: ANDI Yogyakarta.

[11] Han, J., and Kamber, M., (2006). Data Mining: Concepts and Techniques 2nd. United States of America: Elsevier.

[12] Panduan Pendataan Bantuan Langsung TunaiDana Desa (BLT-Dana Desa). (2020). Jakarta. 